\title{
Morphology, molecular phylogeny, and pigment characterization of an isolate of the dinoflagellate Pelagodinium bei from Korean waters
}

\author{
Éric Potvin ${ }^{1, *}$, Hae Jin Jeong ${ }^{2}$, Nam Seon Kang ${ }^{2}$, Jae Hoon Noh $^{3}$ and Eun Jin Yang ${ }^{1}$ \\ ${ }^{1}$ Division of Polar Ocean Environment, Korea Polar Research Institute, Incheon 406-840, Korea \\ ${ }^{2}$ School of Earth and Environmental Sciences, College of Natural Sciences, Seoul National University, Seoul 151-747, Korea \\ ${ }^{3}$ Marine Resources Research Department, KIOST, Ansan 425-600, Korea
}

The dinoflagellate genus Pelagodinium is genetically classified in distinct sub-clades and subgroups. However, it is difficult to determine whether this genetic diversity represents intra- or interspecific divergence within the genus since only the morphology of the type strain of the genus Pelagodinium, Pelagodinium bei, is available. An isolate associated with the genus Pelagodinium from Shiwha Bay, Korea, was recently cultured. This isolate was clustered with 3 to 4 strains from the Atlantic Ocean, Mediterranean Sea, and Indian Ocean. This cluster was distinct from the subgroup more closely associated with $P$. bei. The morphology of the isolate was analyzed using optical and scanning electron microscopy and was almost identical to that of $P$. bei except that this isolate had two series of amphiesmal vesicles (AVs) in the cingulum, unlike $P$. bei that has one series. When the pigment compositions of the isolate and $P$. bei were analyzed using highperformance liquid chromatography, these two strains had peridinin as a major accessory pigment and their pigment compositions were almost identical. In addition, the swimming behaviors of these two strains were very similar. The reexamination of the type culture of $P$. bei revealed two series in the cingulum as for the isolate. The new findings on the number of series of AVs in the cingulum, the pigment composition, and the swimming behaviors suggest that $P$. bei and the isolate are conspecific despite their genetic divergence. This study provides a basis to further understand the molecular classification within Pelagodinium combining genetic, morphological, pigment, and behavioral data.

Key Words: foraminifera; Gymnodinium bei; pelagic symbiont; Suessiaceae; Suessiales

\section{INTRODUCTION}

Marine dinoflagellates are ubiquitous and play diverse roles in marine ecosystems (Jeong et al. 2010, 2012, 2015). The dinoflagellate Gymnodinium bei Spero was a symbiont of the foraminifer Orbulina universa D'Orbigny (Spero 1987). While basic features such as the shape, dimensions, presence of an hypoconal flange and stalked pyrenoids penetrated by thylakoid lamellae, absence of trichocysts, and swimming behavior were recognized, detailed observations of the arrangement of the amphiesmal vesicles (AVs) was lacking (Spero 1987). Thereafter, various dinoflagellate symbionts of planktonic foraminifera sampled worldwide were characterized genetically and referred as "G. bei" (Gast and Caron 1996, Shaked and De Vargas 2006). However, these results suggested that "G. bei" was more closely related to the order Suessiales. Subsequently, a culture of a dinoflagellate isolated from
(9) $\$$ This is an Open Access article distributed under the terms of the Creative Commons Attribution Non-Commercial License (http://creativecommons.org/licenses/by-nc/3.0/) which permits unrestricted non-commercial use, distribution, and reproduction in any medium, provided the original work is properly cited.
Received May 13, 2015, Accepted July 27, 2015

* Corresponding Author

E-mail: ericpotvin@kopri.re.kr

Tel: +82-32-760-5345, Fax: +82-32-760-5399 
Orbulina universa, collected off the coast of Puerto Rico in the Caribbean Sea, was established (Siano et al. 2010). Similar features to G. bei were observed on the collected isolate, suggesting that the cultured dinoflagellate was $G$. bei (Spero 1987). The morphological characterization of the dinoflagellate revealed various features. It had a single elongated apical vesicle (EAV) with a row of small knobs, a feature not present in the genus Gymnodinium. The presence of a type $\mathrm{E}$ extraplastidial eyespot, the arrangement of the AVs in series, and the absence of trichocyst confirmed its affiliation with other symbiotic dinoflagellates and certain genetically related non-symbiotic genera from Suessiales. The arrangement of the series of vesicles of the analyzed strain was unique within the Suessiales, and the pyrenoid ultrastructure was different from other symbiotic dinoflagellates. Furthermore, phylogenetic analysis based on the large subunit ribosomal RNA gene (referred to as LSU rDNA) established that G. bei clusters in an independent, well-supported clade within Suessiales with other sequences of symbiotic dinoflagellates extracted from planktonic foraminifera (Shaked and De Vargas 2006, Siano et al. 2010). This led to the reclassification of G. bei and its combination within the newly erected genus Pelagodinium Siano, Montresor, Probert et De Vargas as Pelagodinium bei (Spero) Siano, Montresor, Probert et De Vargas.

Extraction from pooled symbionts, combined host and symbionts, culture of symbionts established after microdissection, and bulk microplanktonic communities, followed by amplification or cloning, and sequencing have increased our knowledge on the distribution of symbionts associated with foraminifera around the world (Gast and Caron 1996, Shaked and De Vargas 2006, Siano et al. 2010, Decelle et al. 2012, Kok et al. 2014, De Vargas et al. 2015). The distribution of Pelagodinium is mainly based on molecular data. It has been reported in various areas of the Atlantic Ocean (Shaked and De Vargas 2006, Siano et al. 2010, De Vargas et al. 2015), Indian Ocean (Shaked and De Vargas 2006, De Vargas et al. 2015), western North Pacific Ocean (Fujiki et al. 2014, Kok et al. 2014), South Pacific Ocean (Shaked and De Vargas 2006, De Vargas et al. 2015), and Mediterranean Sea (Shaked and De Vargas 2006, Decelle et al. 2012, De Vargas et al. 2015).

In the phylogenetic analysis, the type sequence of $P$. bei clustered in clade $\mathrm{P} 1$, sister of clade $\mathrm{P} 2$, as defined by Shaked and De Vargas (2006) based on LSU rDNA (Siano et al. 2010). There is an important genetic diversity between and within clades P1 and P2 (Shaked and De Vargas 2006). As stated by Siano et al. (2010), only sequences identical to the type sequence should be attributed to $P$. bei. All other sequences should be designated as Pelagodinium sp. awaiting further characterization to verify their actual taxonomic status.

The increase of studies assessing the diversity and distribution in the field using molecular tools makes the detailed characterization of strains associated to the various sequences and their comparison with the type species particularly relevant. However, details of the sulcal area, the internal transcribed spacers and 5.8S ribosomal RNA gene (referred to as ITS rDNA), and the pigment composition of the type species $P$. bei were not assessed, which impaired the comparison between strains.

We recently established a clonal culture of a small dinoflagellate able to grow photosynthetically from Shiwha Bay, Korea, that was related to the genus Pelagodinium. The sequence of this strain was unreported. In this study, we describe the morphological and genetic features, and the swimming behavior of this isolate using optical and scanning electron microscopy (SEM), and phylogenetic analyses based on ITS and LSU rDNA. We also determined the pigment composition using high-performance liquid chromatography (HPLC). To clearly determine the identity of the isolate, we also reinvestigated the type culture of $P$. bei to complement the data previously available (Siano et al. 2010). This study provides a basis to further understand the molecular classification within the genus Pelagodinium.

\section{MATERIALS AND METHODS}

\section{Isolation}

The culture of the isolate from Korea was established from surface sediment samples collected on September 30, 2010 (depth, $11.5 \mathrm{~m}$; surface temperature, $19.6^{\circ} \mathrm{C}$; surface salinity, 11.7 ) from Shiwha Bay, Korea $\left(37^{\circ} 18^{\prime} \mathrm{N}\right.$, $126^{\circ} 36^{\prime}$ E). The surface sediment was collected from an Eckman grab (WILDCO; Wildlife Supply Company, Buffalo, NY, USA) and stored in the dark at $4^{\circ} \mathrm{C}$ until further analyses. To concentrate potentially viable cells, between 1 and $2 \mathrm{~cm}^{3}$ of sediment were sieved through $100-\mu \mathrm{m}$ and 15- $\mu \mathrm{m}$ Nytex meshes with filtered seawater. The 15-100 $\mu \mathrm{m}$ fraction was then transferred to a $100-\mathrm{mL}$ beaker with filtered seawater. A manual vortex was applied and the suspended fraction was recovered. The remnant fraction was incubated in F/2-Si culture medium (Guillard and Ryther 1962) with a salinity of 32 at $20^{\circ} \mathrm{C}$ under a lightdark cycle $14: 10$ at a photon flux of $20 \mu \mathrm{mol} \mathrm{m}^{-2} \mathrm{~s}^{-1}$. A cell swimming in the medium was isolated by micromanipu- 
lation and a monoclonal culture was established after two serial single-cell isolations.

\section{Type culture of Pelagodinium bei}

The culture that was used to establish the holotype of the type species $P$. bei was obtained from the Roscoff Culture Collection (designation RCC \#1491). The type culture was used to determine details not previously assessed for $P$. bei such as the morphology of the sulcal area based on SEM, the ITS rDNA, and the pigment composition based on HPLC analyses.

\section{Optical microscopy}

Cells were observed using a transmitted light inverted microscope (Zeiss Axiovert 200M; Carl Zeiss Ltd., Göttingen, Germany) at magnifications of $\times 50-1,000$ to determine the general morphology and behavior. The measurements were determined with a Zeiss AxioCam MRc5 digital camera (Carl Zeiss Ltd.).

\section{Scanning electron microscopy}

For SEM, cells were fixed with $0.5-1 \%$ osmium tetroxide and rinsed in a dilution of $1: 1$ filtered seawater: distilled water. The cells were then washed in distilled water only. Cells were then subjected to a dehydration series in ethanol (10, 30, 50, 70, 90, and 100\%). The cells were dried using a critical point dryer (CPD 030; BAL-TEC, Balzers, Liechtenstein). Finally, the cells were mounted on stubs, sputter coated with gold-palladium (SCD 005; BAL-TEC), and observed with an FE-scanning electron microscope (AURIGA; Carl Zeiss Ltd.).

\section{Molecular characterization}

For genetic analyses, a culture growing in the conditions described above was filtered through a polycarbonate membrane $(25 \mathrm{~mm}, 3-\mu \mathrm{m}$ pore size Whatman Nucleopore Track-Etch; GE healthcare, Buckinghamshire, UK) and resuspended by vortexing in distilled water in a 1.5-mL microtube (Scientific Specialties Inc., Lodi, CA, USA). The sample was subsequently centrifuged (WiseSpin CF-10 Microcentrifuge; DAIHAN Scientific Co., Ltd., Namyangju, Korea) at 7,500 $\times$ g for $5 \mathrm{~min}$ at room temperature. The cells were immediately subjected to total DNA extraction using the AccuPrep Genomic DNA extraction kit (Bioneer Corp., Daejeon, Korea) according to the manufacturer's instructions.
Amplicons of the ITS and LSU rDNA were obtained. The polymerase chain reaction (PCR) final mix concentrations were as follows: $1 \times$ PCR f-Taq buffer (fTaq DNA polymerase; SolGent Co., Ltd., Daejeon, Korea), $0.2 \mathrm{mM}$ of dNTP (fTaq DNA Polymerase; SolGent Co., Ltd.), 0.4

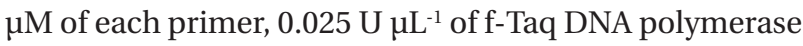
(fTaq DNA polymerase; SolGent Co., Ltd.), and $1.5 \mathrm{mM}$ of $\mathrm{MgCl}_{2}$. A volume of $1.0 \mu \mathrm{L}$ of the DNA extraction was used as template with a final reaction volume of $50 \mu \mathrm{L}$. The amplicons were obtained with the primer pairs ITSF2 and ITSR2 and 5.8 SF and LSUB (Litaker et al. 2003) with 54 and $50^{\circ} \mathrm{C}$ as annealing temperatures (AT), respectively. PCRs were conducted using a thermal cycler (Mastercycler ep, model 5341; Eppendorf AG, Hamburg, Germany) as follows: one activation step at $95^{\circ} \mathrm{C}$ for $2 \mathrm{~min}$, followed by 35 cycles at $95^{\circ} \mathrm{C}$ for $20 \mathrm{~s}$, AT for $40 \mathrm{~s}, 72^{\circ} \mathrm{C}$ for $1 \mathrm{~min}$, and a final elongation step at $72^{\circ} \mathrm{C}$ for $5 \mathrm{~min}$.

Positive and negative controls were used for all amplification reactions. The size of the amplicons was verified on a $1.0 \%$ agarose gel. The products were visualized under a UV lamp. The PCR products were purified using the AccuPrep PCR purification kit (Bioneer Corp.) according to the manufacturer's instructions. The purified PCR products were sent to the Genome Research Facility (School of Biological Science, Seoul National University, Korea) where they were sequenced on an ABI PRISM 3700 DNA Analyzer (Applied Biosystems, Foster City, CA, USA) with the primers used in the PCR.

The sequences of taxa used to construct the phylogenies were obtained from NCBI GenBank. The sequence of the isolate from Korea (strain HJ-2010), and the ITS rDNA sequence of the type species $P$. bei were deposited in GenBank (accession Nos. KP342301 and KP843723, respectively). Our new and reference sequences were aligned using CLUSTAL X v2.0 (Larkin et al. 2007). The alignments were inspected and refined manually using BioEdit v7.0.9.0 (Hall 1999). The aligned matrixes were then analyzed with PAUP v4.0b10 (Swofford 2002). Maximum likelihood was used as a phylogenetic method. The models of nucleotide substitution were determined with Modeltest v7.3 (Posada and Crandall 1998) based on the Akaike information criteria (Posada and Buckley 2004). A heuristic tree search was used to determine the optimal trees. The tree bisection-reconnection algorithm was used with 5 random additions of sequences. The characters were equally weighted and spaces in the alignment were treated as missing data. RAxML v7.0.4 (Stamatakis 2006) was used to calculate bootstrap values using the default algorithm with the general time reversible $+\Gamma$ model of nucleotide substitution and 1,000 replicates. 

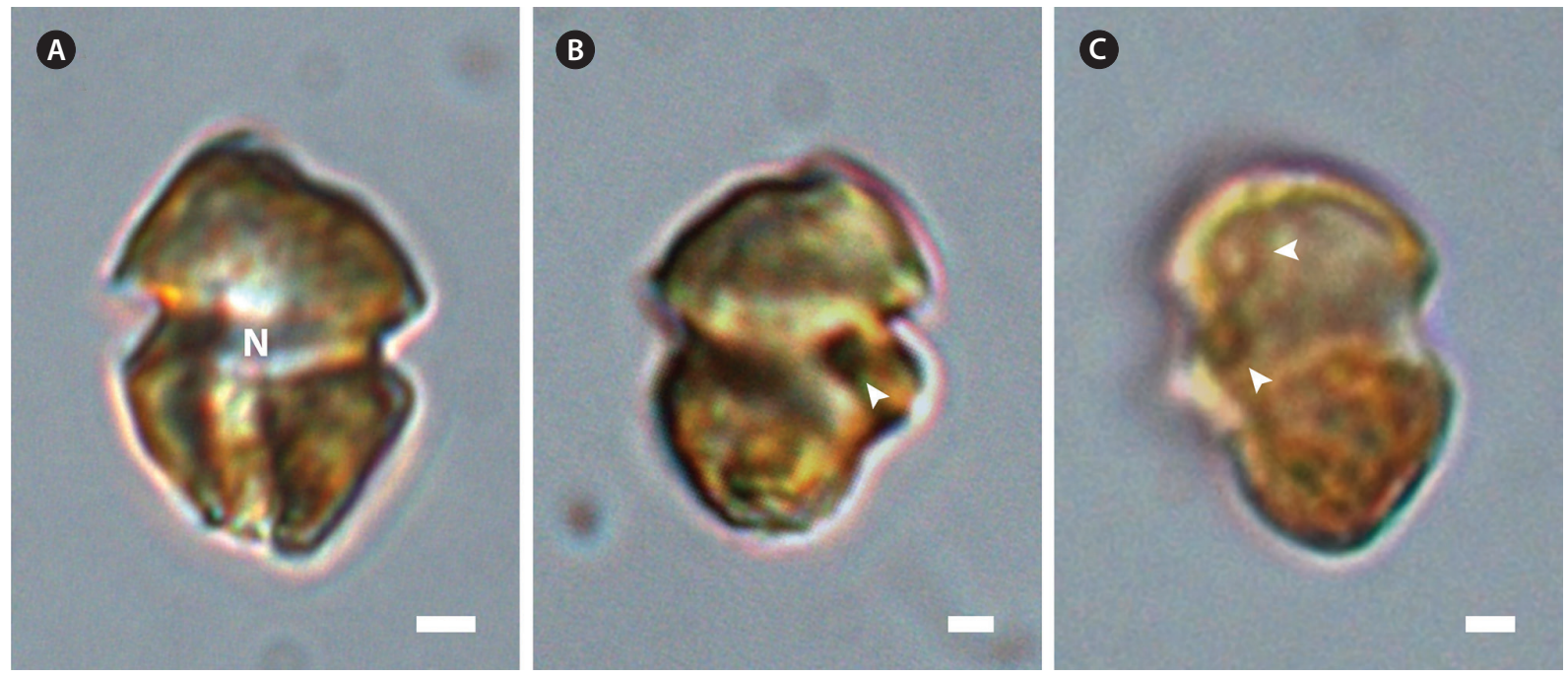

Fig. 1. Micrographs of the isolate taken using optical microscopy. (A) Ventral view illustrating the round to elliptical nucleus (N). (B) Side view. The arrowhead indicates the orange to red eyespot located in the sulcal area. (C) Side view. The arrowheads indicate pyrenoids. Scale bars represent: A-C, $1 \mu \mathrm{m}$.

The matrixes were also analyzed with MrBayes v3.2.3 (Ronquist and Huelsenbeck 2003) for Bayesian analyses. The models previously selected by Modeltest 7.3 were used. Four independent Markov chain Monte Carlo simulations were run simultaneously for 2,000,000 generations. Trees were sampled every 1,000 generations and the first 800 trees were deleted to ensure that the likelihood had reached convergence. A majority-rule consensus tree was created from the remaining 1,201 trees to examine the posterior probabilities of each clade.

\section{Pigment composition}

The pigments were analyzed using HPLC (LC-10A system; Shimadzu Co., Kyoto, Japan) as in Zapata et al. (2000). A volume of culture containing 2,000,000 cells growing in the conditions mentioned previously was used in the analysis. The culture was filtered through a 1.2 $\mu \mathrm{m}$ pore-sized GF/C filter. Three milliliters of $95 \%$ methanol were used for extraction and a Waters C8 column (150 $\times 4.6 \mathrm{~mm}, 3.5-\mu \mathrm{m}$ particle size, $0.01-\mu \mathrm{m}$ pore size; Waters Corporation, Milford, MA, USA) for separation. Pigments were identified by retention times and absorption spectra identical to those of authentic standards, and quantified against standards purchased from DHI Water \& Environment (Hørsholm, Denmark).

\section{RESULTS}

\section{Morphological characterization}

The ranges (and mean \pm standard deviation) of cell length and cell width of living cells from the Korean isolate were 7.9-14.1 $\mu \mathrm{m}(11.1 \pm 1.3, \mathrm{n}=100)$ and 5.1-10.8 $\mu \mathrm{m}$ $(8.3 \pm 1.1, \mathrm{n}=100)$, respectively. The chloroplasts were golden-yellow (Fig. 1). The epicone and hypocone were similar in size (Fig. 1A \& B). The epicone was typically round to elliptical, while the hypocone was either round or slightly asymmetrical in ventral view (Fig. 1). An eyespot was present (Fig. 1B). Pyrenoids were occasionally visible with light microscopy (Fig. 1C).

The cell surface of the isolate from Korea was ornamented with globular knobs and pores that were dispersed randomly (Fig. 2). A hypoconal flange was present, but not clearly expressed in all observed individuals (Fig. 2A). A single EAV ornamented with a row of globular knobs (Fig. 2B \& C) was surrounded by a series of 3-4 quadrangular vesicles and a small squared vesicle (X vesicle) forming the apicals (series 1) (Fig. 2B \& C). However, the apicals were constituted of 4 quadrangular vesicles only once. Another series of vesicles was posterior to the apicals and followed by an anterior intercalary and precingular series that were constituted of 5-8 (series 2), 0-3 (series 3), and 6-8 vesicles (series 4), respectively (Fig. 2D-I). The cingulum was wide, shallow and distinct, located in the median portion of the cell, descending, 

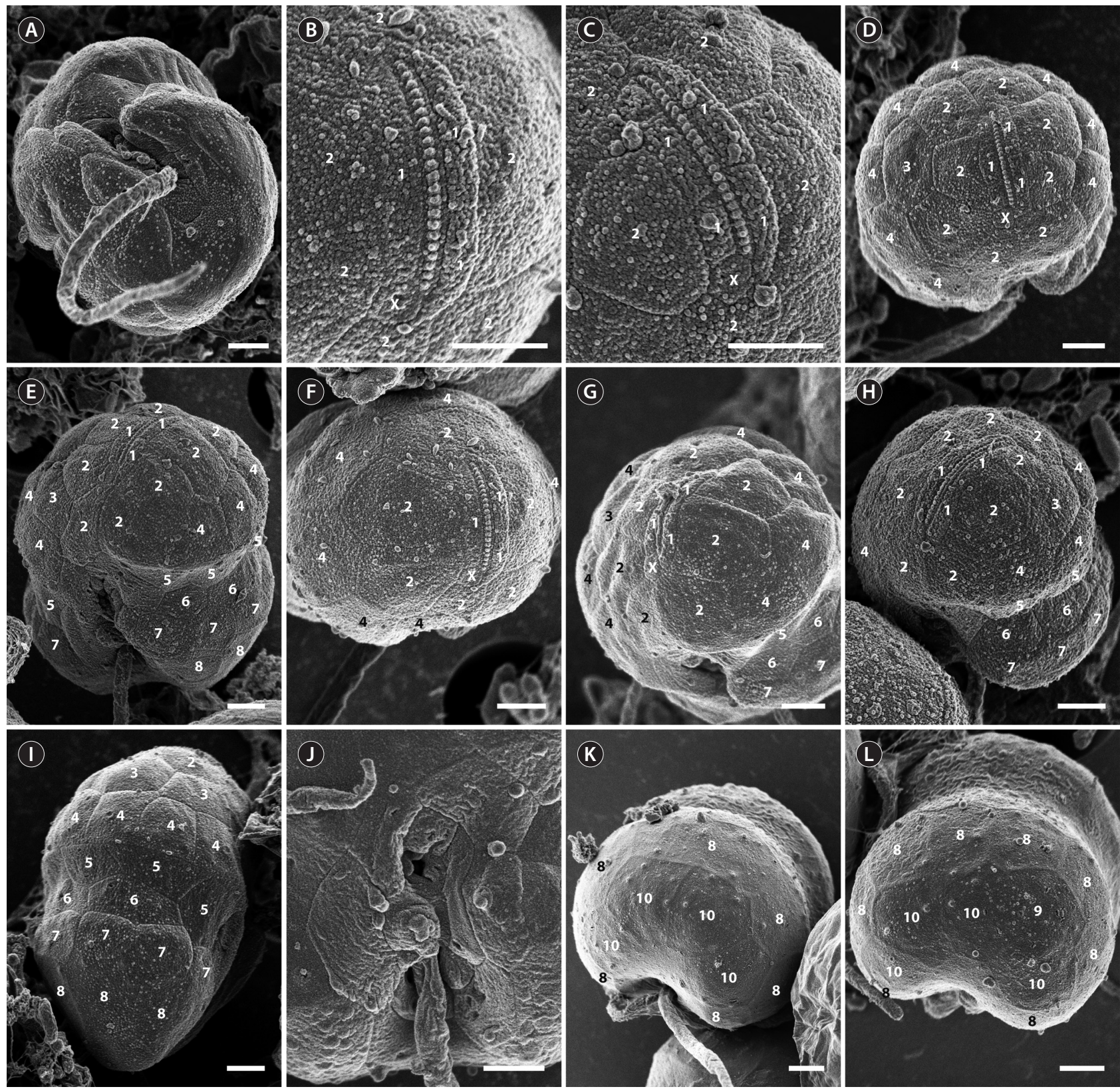

Fig. 2. Micrographs of the isolate taken using scanning electron microscopy. (A) Hypoconal flange. (B \& C) Apical furrow. (D-G) Apical and ventral views. (H) Left view. (I) Right view. (J) Sulcal view. (K \& L) Antapical views. X, small squared vesicle. The amphiesmal vesicles were numbered and assigned to their respective series. Scale bars represent: A-L, $1 \mu \mathrm{m}$.

and displaced by approximately its own width (Fig. 2E). The cingulum contained two series of AVs (series 5 and 6) (Fig. 2E \& I). The number of series in the cingulum was reduced to one when approaching the sulcus, particularly on the right side (Fig. 2E \& I). While the sulcus could be deep and narrow, it was in most cases shallow and wide enabling most of the AVs that constituted it to be seen (Fig. 2J). The sulcus contained 13 AVs (Fig. 2J). The hypo- cone was composed of a series of postcingular small vesicles (series 7) (Fig. 2E \& G-I), anterior to another series of 6-8 hypoconal vesicles (series 8) (Fig. 2K \& L), and 3-4 antapical vesicles (series 10) (Fig. 2K \& L). An intercalary vesicle was sometimes observed preceding the antapicals (series 9) (Fig. 2L).

The SEM fixation of the type culture of $P$. bei from the Caribbean Sea revealed two series of AVs in the cingulum 

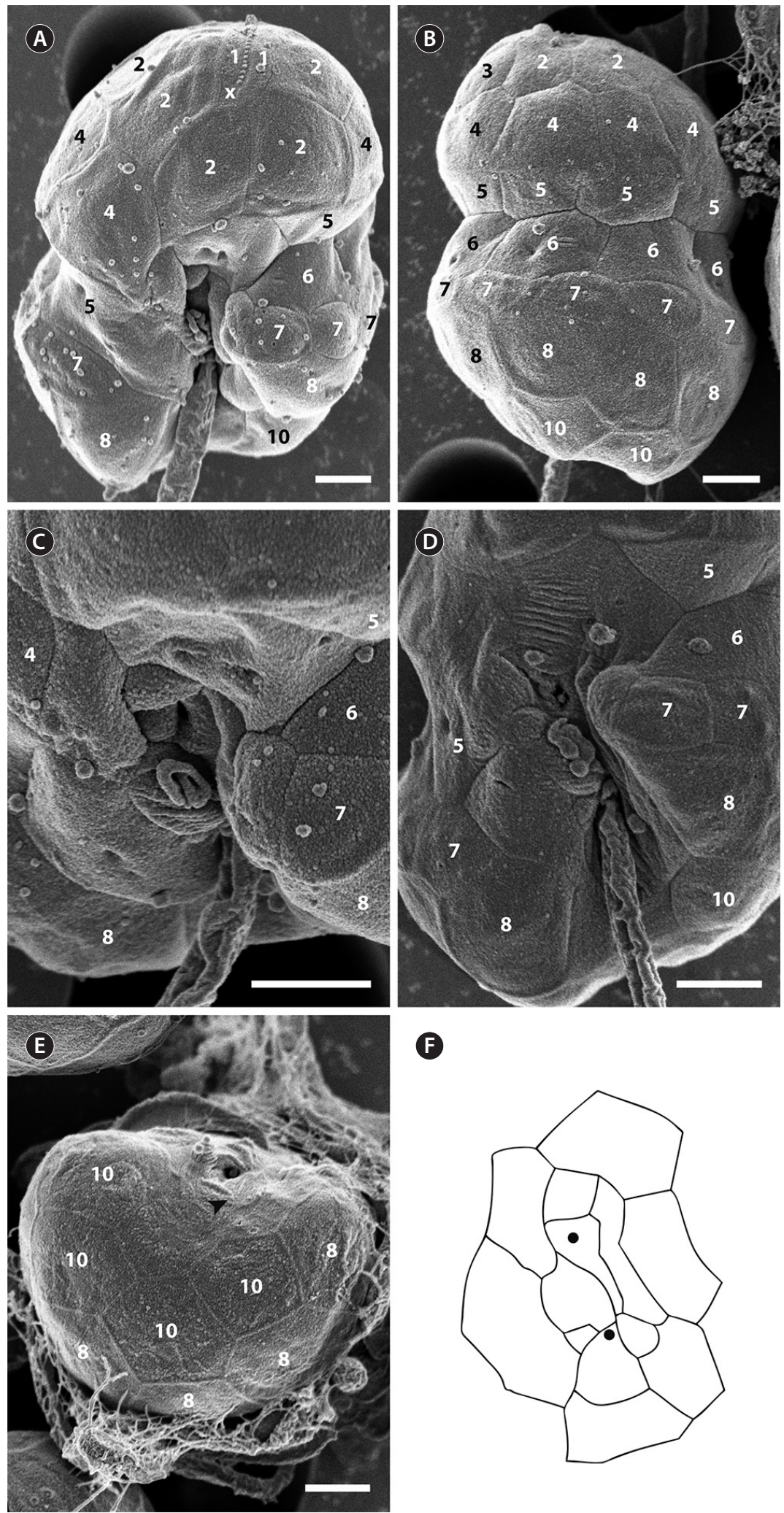

$\boldsymbol{F}$

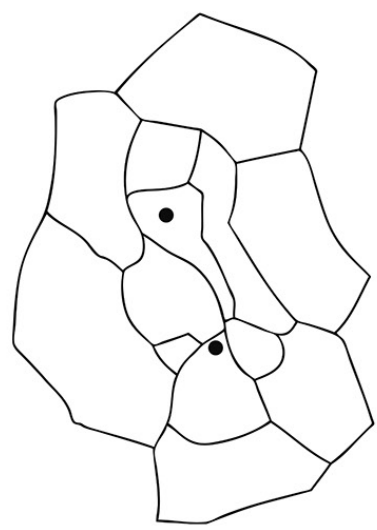

Fig. 3. Micrographs of the type culture of Pelagodinium bei (RCC \#1491) taken using scanning electron microscopy and a schematized view of the sulcal area. (A) Ventral view. (B) Dorsal view. (C-E) Sulcal views. The arrowhead indicates a small amphiesmal vesicle located at the left side of the longitudinal flagellar pore. (F) Drawing of the sulcus. The black circles indicate the location of the flagellar pores of the transversal and longitudinal flagella. The amphiesmal vesicles were numbered and assigned to their respective series. Scale bars represent: A-E, $1 \mu \mathrm{m}$. 


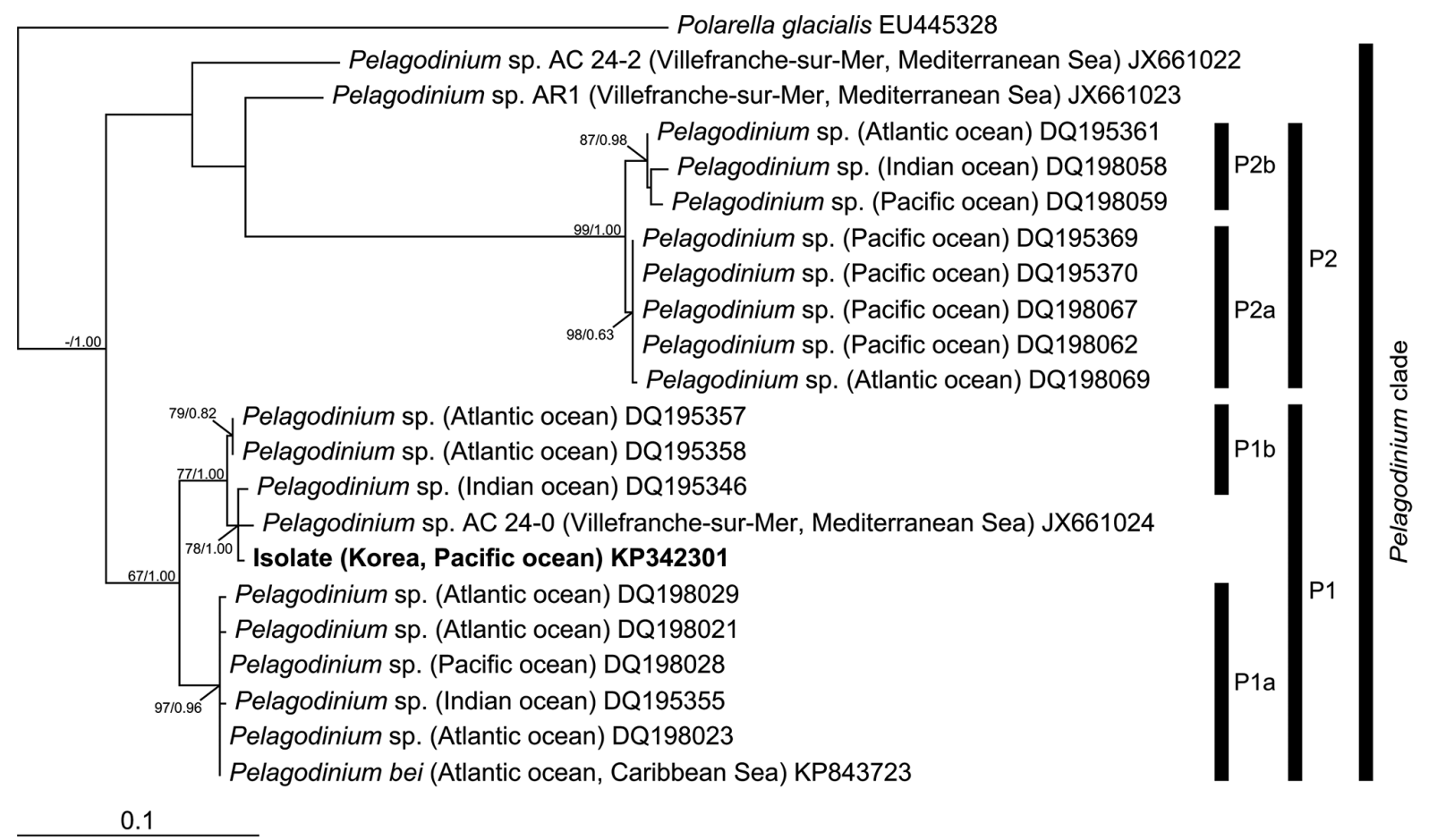

Fig. 4. Maximum likelihood (ML) phylogenetic tree based on 595 aligned nucleotides of the nuclear internal transcribed spacer rDNA using the GTR + G model with Polarella glacialis as an outgroup taxon. Alignment length includes gaps. The parameters were as follows: assumed nucleotide frequencies $A=0.1893, C=0.2283, G=0.2600$, and $T=0.3224$; substitution rate matrix with $G-T=1.0000, A-C=0.5967, A-G=1.7246, A-T=0.9218$, $\mathrm{C}-\mathrm{G}=0.3420, \mathrm{C}-\mathrm{T}=3.2104$; proportion of invariable sites $=0.0000$ and rates for variable sites assumed to follow a gamma distribution with shape parameter $=0.2878$. The numbers at the nodes of the branches indicate the ML bootstrap (left) and Bayesian posterior probability (right) values; only values $\geq 50 \%$ or 0.5 are shown.

with a reduction to one series at the proximity of the sulcus (series 5 and 6) (Fig. 3A \& B) as it has been previously observed for the isolate. The sulcal area was composed of $13 \mathrm{AVs}$ (Fig. 3C-F) and was similar in morphology to the sulcus of the isolate from Korea.

\section{Molecular characterization}

In the phylogenies based on ITS rDNA (Fig. 4) and LSU rDNA (Fig. 5), the isolate from Korea clustered with other sequences associated to the genus Pelagodinium (Figs 4 $\& 5)$. The localities from which the sequences were obtained were not related to their phylogenetic grouping. The isolate clustered within the sub-clade P1 as defined by Shaked and De Vargas (2006), along with P. bei. The sub-clade P1 was subdivided in subgroups also defined by Shaked and De Vargas (2006). The isolate was more closely related to the subgroup P1b, while $P$. bei was more closely related to the subgroup Pla (Figs $4 \& 5$ ). However, the subgroups within the sub-clade P1 were not always clearly supported.

\section{Pigment composition}

The isolate contained chlorophyll $a$ and accessory pigments such as chlorophyll $c 2$, peridinin, diadinoxanthin, diatoxanthin, and $\beta$-carotene (Fig. 6A). The pigment composition of $P$. bei was very similar (Fig. 6B). Zeaxanthin and alloxanthin were detected, but not in both the isolate from Korea and $P$. bei. These pigments were not well represented and might not have been detected in the analyses. The main accessory pigment was peridinin.

\section{Swimming behavior}

The isolate usually swam fast in a straight line. It stopped quickly, changed direction at different angles, and backtracked repetitively. These behaviors were also observed previously for $P$. bei (Siano et al. 2010). 


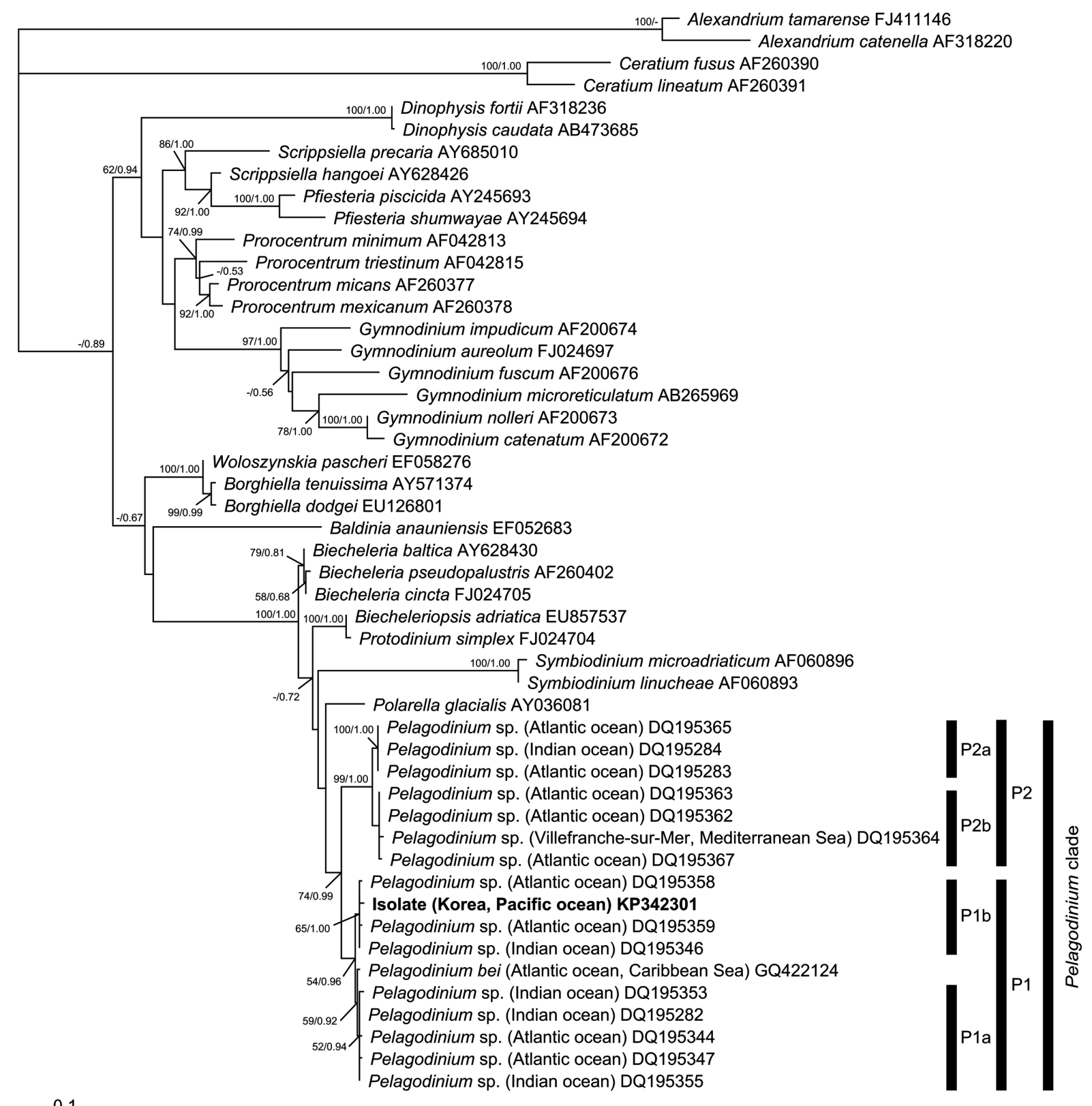

Fig. 5. Maximum likelihood (ML) phylogenetic tree based on 558 aligned nucleotides of the nuclear large subunit rDNA using the TIM + I $+\mathrm{G}$ model with Alexandrium tamarense, $A$. catenella, Ceratium fusus, and $C$. lineatum as outgroup taxa. Alignment length includes gaps. The parameters were as follows: assumed nucleotide frequencies $A=0.2404, C=0.1639, \mathrm{G}=0.2942$, and $\mathrm{T}=0.3014$; substitution rate matrix with $\mathrm{G}-\mathrm{T}$ $=1.0000, A-C=1.0000, A-G=2.2082, A-T=0.7906, C-G=0.7906, C-T=6.5313$; proportion of invariable sites $=0.1258$ and rates for variable sites assumed to follow a gamma distribution with shape parameter $=0.7930$. The numbers at the nodes of the branches indicate the ML bootstrap (left) and Bayesian posterior probability (right) values; only values $\geq 50 \%$ or 0.5 are shown.

\section{DISCUSSION}

The identification of dinoflagellates in the order Suessiales is difficult because many species in this order are small and fragile and SEM fixation does not always result in a clear distinction of the AVs. Thus, classification based on genetic characterizations has been used within several genera such as Pelagodinium and Symbiodinium. Two sub-clades subdivided into subgroups in Pelagodinium and nine clades in Symbiodinium have been suggested based on genetic characterization (Rowan and Powers 1992, Shaked and De Vargas 2006, Pochon and Gates 

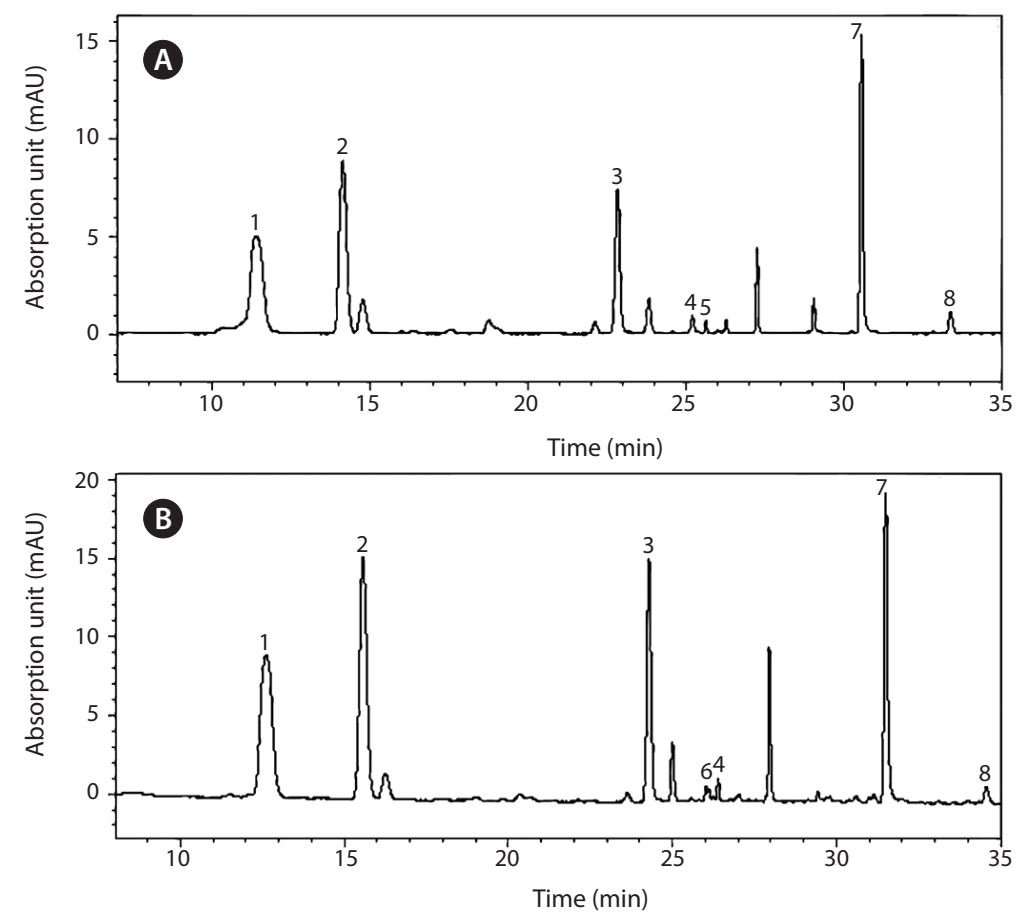

Fig. 6. Pigment composition of the isolate from Korea and Pelagodinium bei derived by high performance liquid chromatography. (A) Chromatogram of the isolate from Korea. (B) Chromatogram of the type culture of P. bei (RCC \#1491). 1, Chlorophyll $c 2 ; 2$, Peridinin; 3 , Diadinoxanthin; 4, Diatoxanthin; 5, Zeaxanthin; 6, Alloxanthin; 7, Chlorophyll $a ; 8, \beta$-carotene.

2010, Siano et al. 2010). There have been some efforts on providing detailed morphology of Symbiodinium and several new species have been established (Hansen and Daugbjerg 2009, Jeong et al. 2014b, LaJeunesse et al. 2015, Lee et al. 2015). However, detailed morphology of only one strain of Pelagodinium, the type culture used to describe $P$. bei, has been reported. Therefore, it is difficult to determine if the genetic classification represents intra- or interspecific variability within the genus Pelagodinium.

This study is the first to report the detailed morphological, behavioral, and pigment characterization of a strain of Pelagodinium closely associated with subgroup Plb, showing a clear similarity with known features of $P$. bei more closely associated with subgroup Pla (Table 1). This suggests that the isolate and $P$. bei are conspecific.

The observations of $P$. bei revealed new morphological features. The cingulum of $P$. bei was previously described with only one series of AVs in the cingulum (Siano et al. 2010). However, the new observations on both strains of $P$. bei revealed that the cingulum contains two series of AVs on the majority of its length with a reduction to one series of AVs at the proximity of the sulcus. The size of the cingular AVs are very similar to those of the postcingular series of small vesicles. Therefore, it is unclear if the post- cingular row of AVs in P. bei should be included within the cingulum. This should be addressed when a more comprehensive view of the diversity within Suessiales is available. This important feature that was consistent between strains of $P$. bei should be carefully considered when further strains belonging to other sub-clades and subgroups are compared within the genus Pelagodinium. While P. bei appeared previously peculiar within Suessiales regarding its cingulum, it now appears more closely related to several other species (Kremp et al. 2005, Moestrup et al. 2008, 2009a, 2009b, Siano et al. 2009, Kang et al. 2011, Balzano et al. 2012, Luo et al. 2013, Daugbjerg et al. 2014, Jeong et al. 2014a, Takahashi et al. 2014).

The sulcal features were useful in determining the taxonomic identity within the same species since they are consistent between strains of $P$. bei. However, the observation of the sulcal area can be impaired by SEM fixation and the observation of all AVs is difficult. Therefore, sulcal features should be considered when possible to properly assess the diversity within Pelagodinium.

$P$. bei use chlorophyll $a$ as the main pigment and peridinin as the main accessory pigment. The presence of peridinin as the main carotenoid pigment is consistent with strains of $P$. bei from Korea and the Caribbean Sea. 
However, peridinin also appears to characterize several species from Suessiales such as Symbiodinium (Venn et al. 2006), Baldinia anauniensis (Hansen et al. 2007), Biecheleria baltica (Kremp et al. 2005), Biecheleriopsis adriatica (Jang et al. 2015), Polarella glacialis (Montresor et al. 2003), and Ansanella granifera (Jeong et al. 2014a).
Diadinoxanthin, another carotenoid pigment, was also well represented in $P$. bei and Symbiodinium (Venn et al. 2006), B. adriatica (Jang et al. 2015), P. glacialis (Montresor et al. 2003), and A. granifera (Jeong et al. 2014a). Based on the available data, well-represented secondary accessory pigments appeared consistent among strains of $P$. bei, but

Table 1. Comparison between the isolate from Korea and Pelagodinium bei from the Caribbean Sea

\begin{tabular}{|c|c|c|}
\hline Features & Isolate & Pelagodinium bei \\
\hline AP length $(\mu \mathrm{m})$ (living cells) & 7.9-14.1 (11.1 \pm 1.3$)$ & $8.8-11.4(10.0 \pm 0.8)^{\mathrm{a}}$ \\
\hline Cell width ( $\mu \mathrm{m})$ (living cells) & $5.1-10.8(8.3 \pm 1.1)$ & $6.0-7.5(6.6 \pm 0.4)^{\mathrm{a}}$ \\
\hline Epicone & Round to elliptical & Round to elliptical $^{\mathrm{a}}$ \\
\hline Hypocone & Slightly asymmetrical or round & Slightly asymmetrical $^{\mathrm{a}}$ \\
\hline Chloroplast & Golden-yellow & Golden-yellow $^{\mathrm{a}}$ \\
\hline Pyrenoids & Present & Present $^{\mathrm{a}}$ \\
\hline Apical furrow & Present & Present $^{\mathrm{a}}$ \\
\hline Cingulum & $\begin{array}{l}\text { Wide and shallow } \\
\text { Descending } \\
\text { Displaced by one cingulum width }\end{array}$ & $\begin{array}{l}\text { Wide and shallow }{ }^{\mathrm{a}} \\
\text { Descending }^{\mathrm{a}} \\
\text { Displaced by one cingulum width }\end{array}$ \\
\hline $\begin{array}{l}\text { Sulcus } \\
\text { Hypoconal flange }\end{array}$ & $\begin{array}{l}\text { Shallow and wide or deep and narrow } \\
\text { Present (not always well expressed) }\end{array}$ & $\begin{array}{l}\text { Deep and narrow }{ }^{\mathrm{a}} \\
\text { Present }^{\mathrm{a}}\end{array}$ \\
\hline Postcingular series of small vesicles & Present & Present $^{\mathrm{a}}$ \\
\hline Number of epiconal series & $3-4$ & $4^{\mathrm{a}}$ \\
\hline Number of cingular series & 1-2 (mainly 2) & $1^{\mathrm{a}}-2^{\mathrm{b}}$ (mainly 2$)$ \\
\hline Number of hypoconal series & $3-4$ & $3-4^{\mathrm{a}, \mathrm{c}}$ \\
\hline $\begin{array}{l}\text { Number of apical vesicles surrounding } \\
\text { the furrow }\end{array}$ & $3-4+X$ & $3+X^{a}$ \\
\hline $\begin{array}{l}\text { Number of vesicles surrounding the } \\
\text { apicals }\end{array}$ & $5-8$ & $7^{\mathrm{a}}$ \\
\hline Number of anterior intercalary vesicles & $0-3$ & $2-3^{\mathrm{a}}$ \\
\hline Number of precingular vesicles & $6-8$ & $8^{\mathrm{a}}$ \\
\hline Number of cingular vesicles & Not count & Not count ${ }^{\mathrm{a}}$ \\
\hline Number of sulcal vesicles & 13 & $13^{\mathrm{b}}$ \\
\hline Number of postcingular small vesicles & Not count & $16-20^{\mathrm{a}}$ \\
\hline $\begin{array}{l}\text { Number of hypoconal vesicles } \\
\text { surrounding the postcingulars }\end{array}$ & $6-8$ & $8^{\mathrm{a}}$ \\
\hline $\begin{array}{l}\text { Number of posterior intercalary } \\
\text { vesicles }\end{array}$ & $0-1$ & $0-1^{\mathrm{a}}$ \\
\hline Number of antapical vesicles & $3-4$ & $3-4^{\mathrm{a}}$ \\
\hline Pigments & $\begin{array}{l}\text { Chlorophyll } a \text {, chlorophyll } c 2 \text {, peridinin, } \\
\text { diadinoxanthin, diatoxanthin, } \beta \text {-carotene, } \\
\text { and zeaxanthin }^{\mathrm{d}}\end{array}$ & $\begin{array}{l}\text { Chlorophyll } a \text {, chlorophyll } c 2 \text {, peri- } \\
\text { dinin, diadinoxanthin, diatoxanthin, } \\
\beta \text {-carotene, and alloxanthin }{ }^{\text {b,d }}\end{array}$ \\
\hline Swimming behavior & $\begin{array}{l}\text { Swam fast in a straight line, stopped quickly, } \\
\text { changed direction at different angles, and } \\
\text { backtracked repetitively }\end{array}$ & $\begin{array}{l}\text { Swam fast in a straight line, stopped } \\
\text { quickly, changed direction at different } \\
\text { angles, and backtracked repetitively }\end{array}$ \\
\hline References & This study & $\begin{array}{l}\text { Siano et al. }(2010)^{\mathrm{a}} \\
\text { This study }^{\mathrm{b}}\end{array}$ \\
\hline
\end{tabular}

The numbers of cingular series and sulcal vesicles of $P$. bei were re-examined and its pigment composition was analyzed in this study.

$\mathrm{AP}$, anteroposterior.

a Siano et al. (2010).

${ }^{\mathrm{b}}$ This study.

'Posterior intercalary series was not considered for P. bei (Siano et al. 2010).

${ }^{d}$ Zeaxanthin and alloxanthin were not well represented and might not have been detected in the analyses. 
were not peculiar to the genus Pelagodinium.

The swimming pattern is consistent between strains of P. bei (Siano et al. 2010, this study) and appears to diverge in some aspects from other species of Suessiales by using repetitive backtracking (Jakobsen et al. 2006, Moestrup et al. 2009b, Siano et al. 2009, Lee et al. 2014, Jang et al. 2015). However, the swimming behavior can be highly variable within the same species (Moestrup et al. 2009b, Jang et al. 2015). Therefore, more detailed observations of strains are required to determine the importance of particular swimming behaviors as distinctive characters for the genus Pelagodinium.

In conclusion, this study established detailed features of an isolate associated with the genus Pelagodinium. While every sequences associated with the genus Pelagodinium should be complemented by morphological data, the results of this study suggest that sequences associated with the sub-clade $\mathrm{P} 1$, including both the subgroups $\mathrm{P} 1 \mathrm{a}$ and P1b, belong to $P$. bei. Furthermore, new features of $P$. bei regarding the cingulum, sulcus, and pigment composition were revealed. The recognition of these features is critical for understanding the diversity within Pelagodinium. These results also provide a basis to further understand the molecular classification within the genus Pelagodinium combining genetic, morphological, pigment, and behavioral data. Further work on strains associated with the sub-clade $\mathrm{P} 2$ will be required in the future.

\section{ACKNOWLEDGEMENTS}

This research was a part of the project titled 'KoreaPolar Ocean in Rapid Transition (KOPRI, PM15040)', funded by the Ministry of Oceans and Fisheries, Korea. It was also funded by the National Research Foundation of Korea (NRF) grant from the Korea government (MSIP) (NRF- 2015-M1A5A1041806) and Management of marine organisms causing ecological disturbance and harmful effect Program of Korea Institute of Marine Science and Technology Promotion (KIMST) of KIMST award to HJJ. Éric Potvin was supported by the Fonds de Recherche du Québec-Nature et Technologies.

\section{REFERENCES}

Balzano, S., Gourvil, P., Siano, R., Chanoine, M., Marie, D., Lessard, S., Sarno, D. \& Vaulot, D. 2012. Diversity of cultured photosynthetic flagellates in the northeast Pacific and Arctic Oceans in summer. Biogeosciences 9:4553-
4571.

Daugbjerg, N., Andreasen, T., Happel, E., Pandeirada, M. S., Hansen, G., Craveiro, S. C., Calado, A. J. \& Moestrup, Ø. 2014. Studies on woloszynskioid dinoflagellates VII. Description of Borghiella andersenii sp. nov.: light and electron microscopy and phylogeny based on LSU rDNA. Eur. J. Phycol. 49:436-449.

Decelle, J., Siano, R., Probert, I., Poirier, C. \& Not, F. 2012. Multiple microalgal partners in symbiosis with the acantharian Acanthochiasma sp. (Radiolaria). Symbiosis $58: 233-244$.

De Vargas, C., Audic, S., Henry, N., Decelle, J., Mahé, F., Logares, R., Lara, E., Berney, C., Le Bescot, N., Probert, I., Carmichael, M., Poulain, J., Romac, S., Colin, S., Aury, J. -M., Bittner, L., Chaffron, S., Dunthorn, M., Engelen, S., Flegontova, O., Guidi, L., Horák, A., Jaillon, O., LimaMendez, G., Lukeš, J., Malviya, S., Morard, R., Mulot, M., Scalco, E., Siano, R., Vincent, F., Zingone, A., Dimier, C., Picheral, M., Searson, S., Kandels-Lewis, S., Tara Oceans Coordinators, Acinas, S. G., Bork, P., Bowler, C., Gorsky, G., Grimsley, N., Hingamp, P., Iudicone, D., Not, F., Ogata, H., Pesant, S., Raes, J., Sieracki, M. E., Speich, S., Stemmann, L., Sunagawa, S., Weissenbach, J., Wincker, P. \& Karsenti, E. 2015. Eukaryotic plankton diversity in the sunlit ocean. Science 348:1261605.

Fujiki, T., Takagi, H., Kimoto, K., Kurasawa, A., Yuasa, T. \& Mino, Y. 2014. Assessment of algal photosynthesis in planktic foraminifers by fast repetition rate fluorometry. J. Plankton Res. 36:1403-1407.

Gast, R. J. \& Caron, D. A. 1996. Molecular phylogeny of symbiotic dinoflagellates from planktonic foraminifera and radiolaria. Mol. Biol. Evol. 13:1192-1197.

Guillard, R. R. L. \& Ryther, J. H. 1962. Studies of marine planktonic diatoms. I. Cyclotella nana Hustedt, and Detonula confervacea (Cleve) Gran. Can. J. Microbiol. 8:229-239.

Hall, T. A. 1999. BioEdit: a user-friendly biological sequence alignment editor and analysis program for Windows 95/98/NT. Nucleic Acids Symp. Ser. 41:95-98.

Hansen, G. \& Daugbjerg, N. 2009. Symbiodinium natans sp. nov.: a "free-living" dinoflagellate from Tenerife (Northeast-Atlantic Ocean). J. Phycol. 45:251-263.

Hansen, G., Daugbjerg, N. \& Henriksen, P. 2007. Baldinia anauniensis gen. et sp. nov.: a 'new' dinoflagellate from Lake Tovel, N. Italy. Phycologia 46:86-108.

Jakobsen, H. H., Everett, L. M. \& Strom, S. L. 2006. Hydromechanical signaling between the ciliate Mesodinium pulex and motile protist prey. Aquat. Microb. Ecol. 44:197-206. Jang, S. H., Jeong, H. J., Moestrup, Ø., Kang, N. S., Lee, S. Y., Lee, K. H., Lee, M. J. \& Noh, J. H. 2015. Morphological, molecular and ecophysiological characterization of the 
phototrophic dinoflagellate Biecheleriopsis adriatica from Korean coastal waters. Eur. J. Phycol. 50:301-317.

Jeong, H. J., Jang, S. H., Moestrup, Ø., Kang, N. S., Lee, S. Y., Potvin, É. \& Noh, J. H. 2014a. Ansanella granifera gen. et sp. nov. (Dinophyceae), a new dinoflagellate from the coastal waters of Korea. Algae 29:75-99.

Jeong, H. J., Lee, S. Y., Kang, N. S., Yoo, Y. D., Lim, A. S., Lee, M. J., Kim, H. S., Yih, W., Yamashita, H. \& LaJeunesse, T. C. 2014b. Genetics and morphology characterize the dinoflagellate Symbiodinium voratum, n. sp., (Dinophyceae) as the sole representative of Symbiodinium clade E. J. Eukaryot. Microbiol. 61:75-94.

Jeong, H. J., Lim, A. S., Franks, P. J. S., Lee, K. H., Kim, J. H., Kang, N. S., Lee, M. J., Jang, S. H., Lee, S. Y., Yoon, E. Y., Park, J. Y., Yoo, Y. D., Seong, K. A., Kwon, J. E. \& Jang, T. Y. 2015. A hierarchy of conceptual models of red-tide generation: nutrition, behavior, and biological interactions. Harmful Algae 47:97-115.

Jeong, H. J., Yoo, Y. D., Kang, N. S., Lim, A. S., Seong, K. A., Lee, S. Y., Lee, M. J., Lee, K. H., Kim, H. S., Shin, W., Nam, S. W., Yih, W. \& Lee, K. 2012. Heterotrophic feeding as a newly identified survival strategy of the dinoflagellate Symbiodinium. Proc. Natl. Acad. Sci. U. S. A. 109:12604-12609.

Jeong, H. J., Yoo, Y. D., Kim, J. S., Seong, K. A., Kang, N. S. \& Kim, T. H. 2010. Growth, feeding, and ecological roles of the mixotrophic and heterotrophic dinoflagellates in marine planktonic food webs. Ocean Sci. J. 45:65-91.

Kang, N. S., Jeong, H. J., Yoo, Y. D., Yoon, E. Y., Lee, K. H., Lee, K. \& Kim, G. 2011. Mixotrophy in the newly described phototrophic dinoflagellate Woloszynskia cincta from western Korean waters: feeding mechanism, prey species and effect of prey concentration. J. Eukaryot. Microbiol. 58:152-170.

Kok, S. P., Tsuchiya, K., Komatsu, K., Toda, T. \& Kurosawa, N. 2014. The protistan microplankton community along the Kuroshio Current revealed by $18 \mathrm{~S}$ rRNA gene clone analysis: a case study of the differences in distribution interplay with ecological variability. Plankton Benthos Res. 9:71-82.

Kremp, A., Elbrächter, M., Schweikert, M., Wolny, J. L. \& Gottschling, M. 2005. Woloszynskia halophila (Biecheler) comb. nov.: a bloom-forming cold-water dinoflagellate co-occurring with Scrippsiella hangoei (Dinophyceae) in the Baltic Sea. J. Phycol. 41:629-642.

LaJeunesse, T. C., Lee, S. Y., Gil-Agudelo, D. L., Knowlton, N. \& Jeong, H. J. 2015. Symbiodinium necroappetens sp. nov. (Dinophyceae): an opportunist 'zooxanthella' found in bleached and diseased tissues of Caribbean reef corals. Eur. J. Phycol. 50:223-238.

Larkin, M. A., Blackshields, G., Brown, N. P., Chenna, R., Mc-
Gettigan, P. A., McWilliam, H., Valentin, F., Wallace, I. M., Wilm, A., Lopez, R., Thompson, J. D., Gibson, T. J. \& Higgins, D. G. 2007. Clustal W and Clustal X version 2.0. Bioinformatics 23:2947-2948.

Lee, S. K., Jeong, H. J., Jang, S. H., Lee, K. H., Kang, N. S., Lee, M. J. \& Potvin, É. 2014. Mixotrophy in the newly described dinoflagellate Ansanella granifera: feeding mechanism, prey species, and effect of prey concentration. Algae 29:137-152.

Lee, S. Y., Jeong, H. J., Kang, N. S., Jang, T. Y., Jang, S. H. \& Lajeunesse, T. C. 2015. Symbiodinium tridacnidorum sp. nov., a dinoflagellate common to Indo-Pacific giant clams, and a revised morphological description of Symbiodinium microadriaticum Freudenthal, emended Trench \& Blank. Eur. J. Phycol. 50:155-172.

Litaker, R. W., Vandersea, M. W., Kibler, S. R., Reece, K. S., Stokes, N. A., Steidinger, K. A., Millie, D. F., Bendis, B. J., Pigg, R. J. \& Tester, P. A. 2003. Identification of Pfiesteria piscicida (Dinophyceae) and Pfiesteria-like organisms using internal transcribed spacer-specific PCR assays. J. Phycol. 39:754-761.

Luo, Z., Yang, W., Xu, B. \& Gu, H. 2013. First record of Biecheleria cincta (Dinophyceae) from Chinese coasts, with morphological and molecular characterization of the strains. Chin. J. Oceanol. Limnol. 31:835-845.

Moestrup, Ø., Hansen, G. \& Daugbjerg, N. 2008. Studies on woloszynskioid dinoflagellates III: on the ultrastructure and phylogeny of Borghiella dodgei gen. et sp. nov., a cold-water species from Lake Tovel, N. Italy, and on $B$. tenuissima comb. nov. (syn. Woloszynskia tenuissima). Phycologia 47:54-78.

Moestrup, Ø., Lindberg, K. \& Daugbjerg, N. 2009a. Studies on woloszynskioid dinoflagellates IV: The genus Biecheleria gen. nov. Phycol. Res. 57:203-220.

Moestrup, Ø., Lindberg, K. \& Daugbjerg, N. 2009b. Studies on woloszynskioid dinoflagellates V. Ultrastructure of Biecheleriopsis gen. nov., with description of Biecheleriopsis adriatica sp. nov. Phycol. Res. 57:221-237.

Montresor, M., Lovejoy, C., Orsini, L., Procaccini, G. \& Roy, S. 2003. Bipolar distribution of the cyst-forming dinoflagellate Polarella glacialis. Polar Biol. 26:186-194.

Pochon, X. \& Gates, R. D. 2010. A new Symbiodinium clade (Dinophyceae) from soritid foraminifera in Hawai'i. Mol. Phylogenet. Evol. 56:492-497.

Posada, D. \& Buckley, T. R. 2004. Model selection and model averaging in phylogenetics: advantages of Akaike Information Criterion and Bayesian approaches over likelihood ratio tests. Syst. Biol. 53:793-808.

Posada, D. \& Crandall, K. A. 1998. MODELTEST: testing the model of DNA substitution. Bioinformatics 14:817-818. 
Ronquist, F. \& Huelsenbeck, J. P. 2003. MrBayes 3: Bayesian phylogenetic inference under mixed models. Bioinformatics 19:1572-1574.

Rowan, R. \& Powers, D. A. 1992. Ribosomal RNA sequences and the diversity of symbiotic dinoflagellates (zooxanthellae). Proc. Natl. Acad. Sci. U. S. A. 89:3639-3643.

Shaked, Y. \& De Vargas, C. 2006. Pelagic photosymbiosis: rDNA assessment of diversity and evolution of dinoflagellate symbionts and planktonic foraminiferal hosts. Mar. Ecol. Prog. Ser. 325:59-71.

Siano, R., Kooistra, W. H. C. F., Montresor, M. \& Zingone, A. 2009. Unarmoured and thin-walled dinoflagellates from the Gulf of Naples, with the description of Woloszynskia cincta sp. nov. (Dinophyceae, Suessiales). Phycologia 48:44-65.

Siano, R., Montresor, M., Probert, I., Not, F. \& De Vargas, C. 2010. Pelagodinium gen. nov and P. béii comb. nov., a dinoflagellate symbiont of planktonic Foraminifera. Protist 161:385-399.

Spero, H. J. 1987. Symbiosis in the planktonic foraminifer, Orbulina universa, and the isolation of its symbiotic dinoflagellate, Gymnodinium béii sp. nov. J. Phycol.
23:307-317.

Stamatakis, A. 2006. RAxML-VI-HPC: maximum likelihoodbased phylogenetic analyses with thousands of taxa and mixed models. Bioinformatics 22:2688-2690.

Swofford, D. L. 2002. PAUP*: Phylogenetic Analysis Using Parsimony (*and Other Methods), version 4. Sinauer Associates, Sunderland, MA.

Takahashi, K., Sarai, C. \& Iwataki, M. 2014. Morphology of two marine woloszynskioid dinoflagellates, Biecheleria brevisulcata sp. nov. and Biecheleriopsis adriatica (Suessiaceae, Dinophyceae), from Japanese coasts. Phycologia 53:52-65.

Venn, A. A., Wilson, M. A., Trapido-Rosenthal, H. G., Keely, B. J. \& Douglas, A. E. 2006. The impact of coral bleaching on the pigment profile of the symbiotic alga, Symbiodinium. Plant Cell Environ. 29:2133-2142.

Zapata, M., Rodríguez, F. \& Garrido, J. L. 2000. Separation of chlorophylls and carotenoids from marine phytoplankton: a new HPLC method using a reversed phase C8 column and pyridine-containing mobile phases. Mar. Ecol. Prog. Ser. 195:29-45. 